\title{
Fas and Fas ligand expression in inflamed islets in pancreas sections of patients with recent-onset Type I diabetes mellitus
}

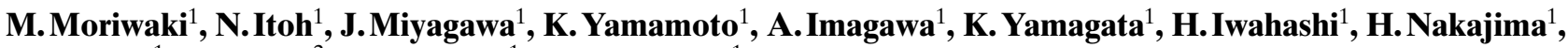 \\ M.Namba ${ }^{1}$, S. Nagata ${ }^{2}$, T.Hanafusa ${ }^{1}$, Y. Matsuzawa ${ }^{1}$ \\ ${ }^{1}$ Department of Internal Medicine and Molecular Science, Graduate School of Medicine, Osaka University, Osaka, Japan \\ ${ }^{2}$ Department of Genetics, Graduate School of Medicine, Osaka University, Osaka, Japan
}

\begin{abstract}
Aims/hypothesis. Type I (insulin-dependent) diabetes results mainly from T-cell-mediated autoimmune destruction of pancreatic beta cells. Cytotoxic T lymphocytes destroy target cells via a perforin-based or Fas-based mechanism. Our previous study indicated that the Fas-Fas ligand (FasL) pathway is required for the development of autoimmune diabetes in the NOD mouse. We now investigated whether or not the Fas-FasL system is involved in the beta-cell destruction in human Type I diabetes.

Methods. We immunohistochemically analysed pancreas biopsy specimens of 13 recent-onset patients.

Results. Pancreatic islets were identified but showed various degrees of reduction in beta-cell volume in all patients. Out of 13 patients 6 had insulitis. In these 6 patients Fas was expressed in both the islets and in-
\end{abstract}

filtrating cells but not in either cell type in the 7 other patients without insulitis. Double immunostaining showed that Fas was positive in 92.2 to $97.7 \%$ of beta cells but only in 17.6 to $46.7 \%$ of alpha cells in Fas-positive, insulin-remaining islets. We found FasL was expressed exclusively in islet-infiltrating cells in patients with insulitis. Double immunostaining revealed that the most prevalent phenotype of FasLpositive cells was CD8, which was followed by macrophages and CD4.

Conclusion/interpretation. The interaction between Fas on beta cells and FasL on infiltrating cells might trigger selective apoptotic beta-cell death in inflamed islets, leading to immune-mediated Type I diabetes. [Diabetologia (1999) 42: 1332-1340]

Keywords Type I diabetes, Fas, Fas ligand, insulitis, human pancreas, apoptosis.
Type I (insulin-dependent) diabetes mellitus is thought to be a cell-mediated autoimmune disease characterized by the selective destruction of pancreatic beta cells $[1,2]$. Several lines of evidence have established a critical role for autoreactive lymphocytes in the pathogenesis of this disease. Peripheral blood mononuclear cells from people with or at increased

Received: 3 March 1999 and in final revised form: 9 July 1999

Corresponding author: Dr. T. Hanafusa, Dept. of Internal Medicine and Molecular Science, Graduate School of Medicine, B5, Osaka University, 2-2 Yamada-oka, Suita, Osaka 565-0871, Japan

Abbreviations: GAD, Glutamic acid decarboxylase; FasL, Fas ligand; NOD, Non-obese diabetic; lpr, lymphoproliferation; IFN, interferon; CTL, cytotoxic T lymphocytes; Z-VAD, carbobenzoxy-Val-Ala-Asp-CH2-2,6-dichlorobenzolate. risk for Type I diabetes showed increased reactivity to beta cell autoantigens, such as insulin secretory granule proteins and glutamic acid decarboxylase (GAD) [3-5]. Type I diabetes was transferred by bone marrow transplantation between HLA-matched siblings [6]. Mononuclear cell infiltration into the pancreatic islets (insulitis) and the reduction of insulin-producing beta cells have been recognized as pathological features of the pancreas of recent-onset Type I diabetes [7-10]. The infiltrate was composed of $\mathrm{CD}^{+} \mathrm{T}, \mathrm{CD} 4^{+} \mathrm{T}, \mathrm{B}$ lymphocytes and macrophages: in most cases, $\mathrm{CD} 8^{+}$ T-cells were predominant [8-10]. There was also the hyperexpression of MHC class I molecules in inflamed islet cells [8-11]. CD8 ${ }^{+}$T-cells interact with target antigens in the context of self-MHC class I molecules [12] and $\mathrm{CD} 8^{+} \mathrm{T}$-cells are major effectors of cell-mediated cytotoxicity, and the killing of beta cells by $\mathrm{CD} 8^{+}$cyto- 
toxic T lymphocytes (CTLs) is thought to play a major part in the insulitis lesion.

T-cell-mediated cytotoxicity comprises two major pathways: Fas-dependent and perforin-dependent mechanisms [13-15]. Fas (APO-1/CD95) is a Type I membrane protein that belongs to the $\mathrm{TNF} /$ nerve growth factor receptor family and mediates apoptosis [16]. Fas mRNA is abundantly expressed in a variety of organs including the thymus, liver, heart and kidney [17]. As a natural ligand for Fas, Fas ligand (FasL/CD95L) was identified as a type II membrane protein that belongs to the TNF family [18]. FasL is predominantly expressed in activated T-cells and mediates Fas-bearing target cell death [19-21].

The considerable contribution of the Fas-FasL system in autoimmune diabetes has been shown recently by studies of Fas-deficient, non-obese diabetic (NOD)-lymphoproliferation (lpr) /lpr mice, which are devoid of both spontaneous and adoptively transferred diabetes $[22,23]$. Most recent studies suggested, however, that Fas-FasL system plays only a minor part in beta-cell destruction in NOD mice [24, 25]. To investigate whether or not the Fas-FasL system is involved in the pathogenesis of human Type I diabetes, we analysed pancreas biopsy specimens of patients with recent-onset Type I diabetes for the expression of Fas and FasL.

\section{Materials and methods}

Subjects. We examined 13 patients with recent-onset Type I diabetes (11 men and 2 women). All patients fulfilled the criteria of the National Diabetes Date Group for insulin-dependent diabetes mellitus [26] and presented with the typical abrupt disease onset with ketosis. They were assumed to have Type I diabetes under the new classification reported by the expert committee on the diagnosis and classification of diabetes mellitus [27]. The patients included seven (cases 1-7) from our former study [9]. The mean age of the 13 patients was 25.5 (range 16-46) years and the mean duration of Type I diabetes was 2.7 (range 1-5) months. Islet cell antibodies were detected in seven patients by an indirect immunofluorescence method and GAD antibodies were determined in six patients with a radioimmunoassay kit (Hoechst-Japan, Tokyo, Japan).

Pancreas sections. The study protocol was primarily approved by the ethics committee of Osaka University Medical School and carried out in accordance with the Declaration of Helsinki. Written informed consent was obtained from all patients before the study. Pancreas biopsy was as described previously [28] without any complications. Briefly, a laparoscope was introduced into the abdominal cavity from the skin incision site near the navel. Under direct inspection, one to three pieces of tissue were obtained from the body of the pancreas with biopsy forceps. Blocks of the biopsy specimen tissue were frozen immediately in dry ice-isopentane, and 5- $\mu \mathrm{m}$-thick sections were cut on a cryostat. About 300 consecutive sections were cut from each biopsy specimen block and stored at $-80^{\circ} \mathrm{C}$ until use. Parts of the pancreas body from four subjects who underwent partial pancreatectomy for gastric cancer were used as the normal control.
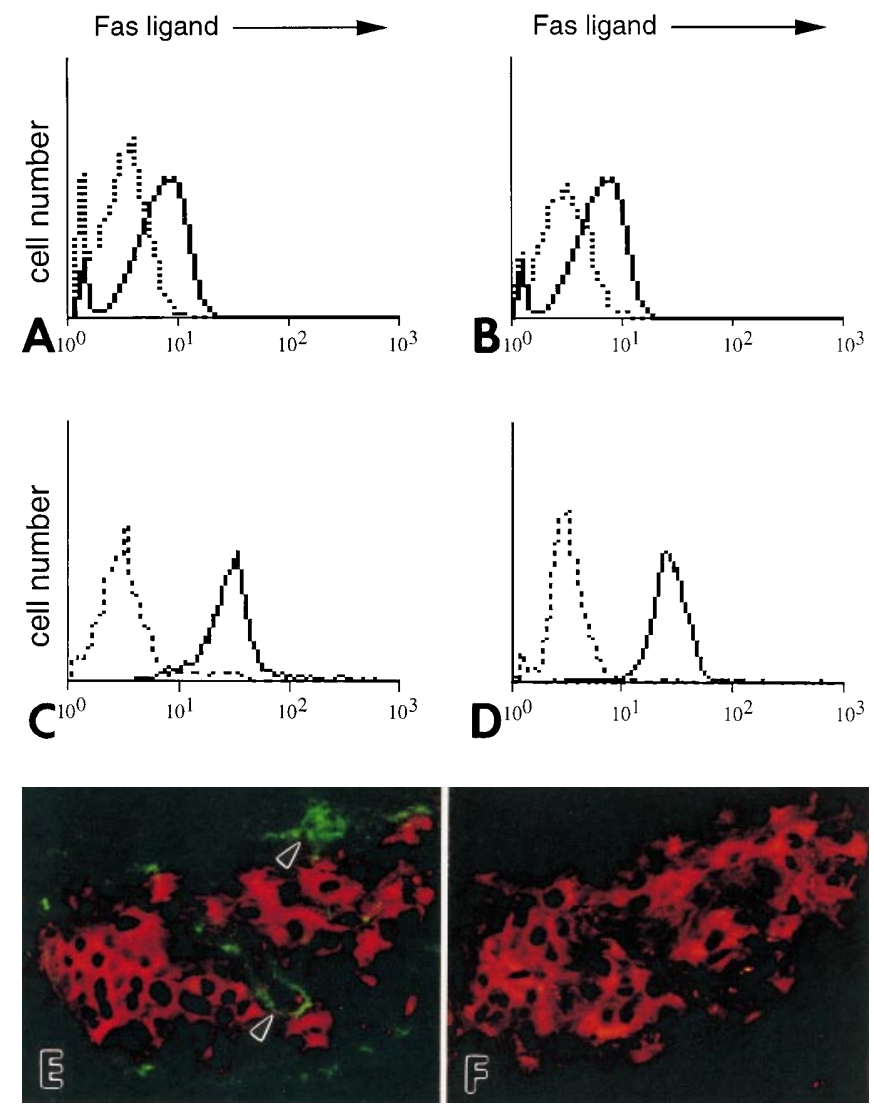

Fig. 1 A-F. Expression of FasL in human PBLs stimulated with $5 \mu \mathrm{g} / \mathrm{ml}$ ConA, $10 \mathrm{ng} / \mathrm{ml} \mathrm{IL-2,} 10 \mathrm{ng} / \mathrm{ml} \mathrm{PMA}$ and $500 \mathrm{ng} / \mathrm{ml}$ of ionomycin (A, B). See Methods for details. The PBLs were incubated with anti-human FasL antibody, H707 (solid line), and with normal rabbit serum (dashed line) (A). The PBLs were incubated with anti-human FasL antibody, H707 (solid line) and with $\mathrm{H} 707$ pre-absorbed with FasL peptide (dashed line) (B). Expression of FasL in Jurkat cells stimulated with $1 \mu \mathrm{g} /$ $\mathrm{ml}$ of anisomycin $(\mathbf{C})$ and $3300 \mathrm{rad}$ of gamma irradiation (D) in the presence of $30 \mathrm{mmol} / \mathrm{l}$ of Z-VAD. The stimulated Jurkat cells were incubated with anti-human FasL antibody, H707 (solid line) and with normal rabbit serum (dashed line). Two consecutive pancreas sections of a recent-onset Type I diabetic patient $(\mathbf{E}, \mathbf{F})$ were stained with non-absorbed, anti-FasL antibody, H707 (E) or H707 pre-absorbed with FasL peptide (F) (green) and anti-insulin (red), respectively $(\times 400)$. FasL-positive cells were detected in and around the islet, as indicated by arrowheads $(\mathbf{E})$. In the next control section, positive FasL staining was completely absorbed using $\mathrm{H} 707$ pre-incubated with FasL peptide $(\mathbf{F})$

Antibodies. The following antibodies were used in this study : monoclonal anti-Fas antibody (4B4-B3) was prepared by one of the authors (S. Nagata) and the specificity was confirmed by western blotting. Polyclonal rabbit anti-human Fas ligand antibody (H707, Nichirei, Tokyo, Japan) was reported to be suitable for immunohistochemistry [29]. The specificity of the H707 antibody was assessed by an absorption test. Human PBLs were cultured at $37^{\circ} \mathrm{C}$ for 3 days with $5 \mu \mathrm{g} / \mathrm{ml}$ ConA and $10 \mathrm{ng} / \mathrm{ml} \mathrm{IL-2,} \mathrm{then} \mathrm{stimulated} \mathrm{with} 10 \mathrm{ng} / \mathrm{ml}$ phorbol 12myristate 13-acetate (PMA) and $500 \mathrm{ng} / \mathrm{ml}$ of ionomycin for $12 \mathrm{~h}$. Under these stimulations, PBLs have been shown to express FasL [30]. And Jurkat cells were stimulated for $3300 \mathrm{rad}$ of gamma irradiation and $1 \mu \mathrm{g} / \mathrm{ml}$ of anisomycin (Sigma chem- 

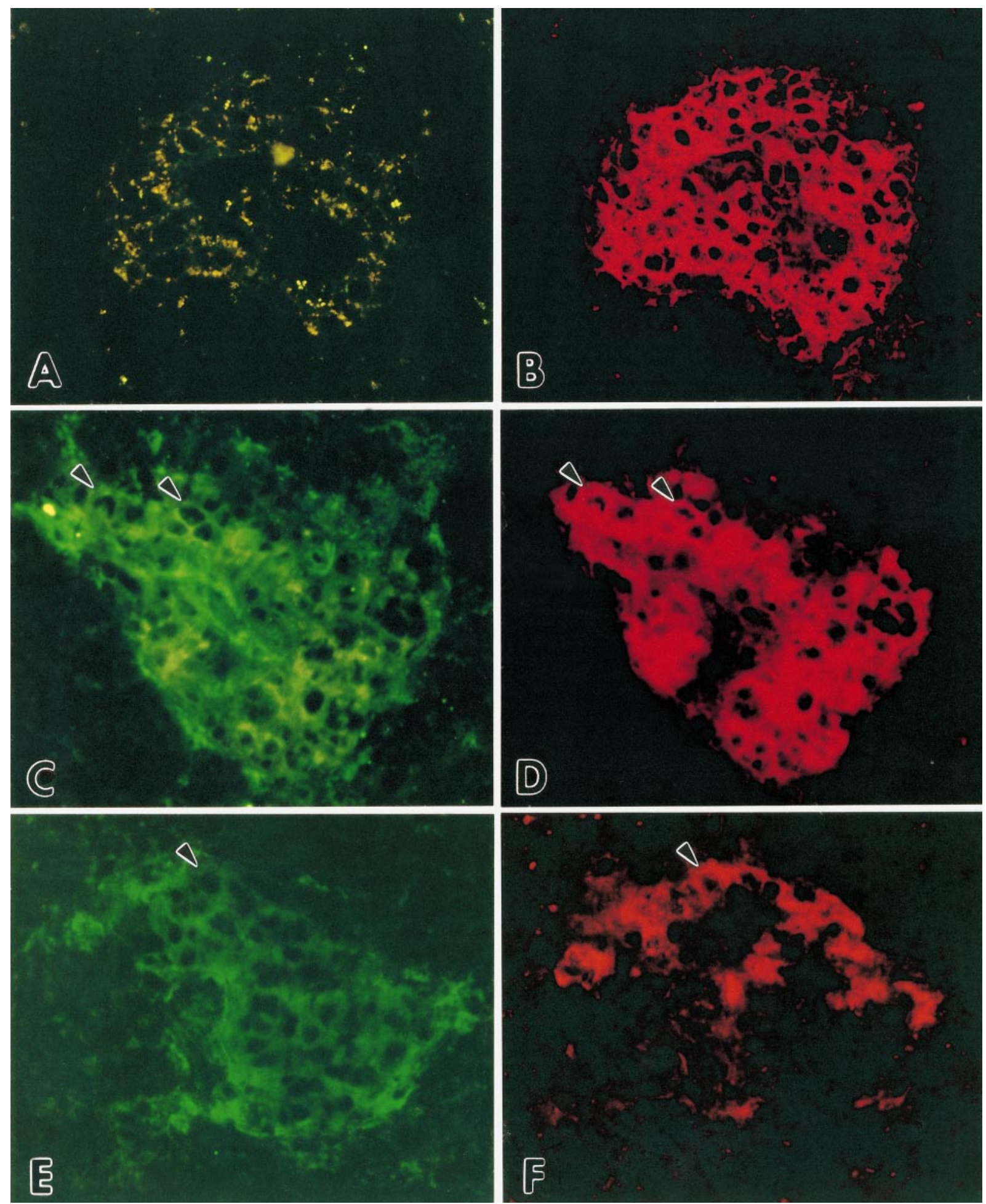

Fig. 2 A-F. Pancreas sections of a control subject $(\mathbf{A}, \mathbf{B})$ and a recent-onset Type I diabetic patient $(\mathbf{C}, \mathbf{D}, \mathbf{E}, \mathbf{F})$ were stained with anti-Fas antibody (green; $\mathbf{A}, \mathbf{C}, \mathbf{E}$ ) and anti-insulin (red; $\mathbf{B}, \mathbf{D})$ and anti-glucagon antibody $(\mathrm{red} ; \mathbf{F})(\times 400)$. Fas is positive in the islet of a Type I diabetic patient $(\mathbf{C}, \mathbf{E})$ but not in the islet of the control subject $(\mathbf{A})$. Double immunostaining of Fasstained sections with anti-insulin $(\mathbf{B}, \mathbf{D})$ and anti-glucagon $(\mathbf{F})$ antibodies (red) shows that Fas-positive cells are mostly insulin-positive cells and partly glucagon-positive cells. Representative double-positive cells are indicated by arrowheads

ical company, Saint Louis, Mo., USA) in the presence of $30 \mathrm{mmol} / \mathrm{l}$ of Z-VAD (carbobenzoxy-Val-Ala-Asp-CH2-2,6dichlorobenzolate) (Phoenix Pharmaceuticals, Mountain View, Calif., USA) which interferes with the activation of CPP32 and IL-1 $\beta$ converting enzyme (ICE)-like caspase [31]. Under these stimulations, Jurkat cells have been shown to express FasL [31]. The stimulated PBLs and Jurkat cells were fixed with $1 \%$ paraformaldehyde containing PBS for $20 \mathrm{~min}$ and made permeable with $0.1 \%$ Saponin/0.1\%FCS/PBS for $5 \mathrm{~min}$. The fixed cells were then incubated for $30 \mathrm{~min}$ at $4{ }^{\circ} \mathrm{C}$ 
with anti-human FasL antibody or the antibody pre-incubated overnight with excessive human FasL peptide (molar ratio: peptide/antibody $=11.1$ ). The cells were washed with PBS, incubated for $30 \mathrm{~min}$ at $4{ }^{\circ} \mathrm{C}$ with fluorescein isothiocyanate (FITC) conjugated goat anti-rabbit IgG $(\mathrm{H}+\mathrm{L})$ (Zymed Laboratories, San Francisco, Calif., USA), then analysed on a FACScan (Fig. 1A-D). In addition, the specificity of the antibody in immunostaining was also assessed by an absorption test. After air-drying for $30 \mathrm{~min}$, the sections were prefixed in cold acetone for $10 \mathrm{~min}$. Endogenous biotin was blocked using a biotin blocking system (Dako-Japan, Kyoto, Japan). The first incubation was conducted overnight at $4{ }^{\circ} \mathrm{C}$ either with non-absorbed anti-FasL or antibody pre-incubated overnight with excessive human FasL peptide. After washing in PBS, the sections were incubated at room temperature for $60 \mathrm{~min}$ with biotinylated goat anti-rabbit immunoglobulins (Igs) (Vector Laboratories, Burlingame, Calif., USA) and for an additional 30 min with FITC-avidin D (Vector Laboratories). The above mentioned procedure was followed by two consecutive incubations with the following anti-insulin antibodies (Dako-Japan) combined with the rhodamine-conjugated goat anti-guinea pig Igs (Chemicon International, Temecula, Calif., USA). The section was washed in PBS, mounted with PermaFluor (Shandon/Lipshaw, Pittsburgh, Pa., USA) and observed using a fluorescence microscope (AX-80 T and AX80TR, Olympus, Tokyo, Japan).

PBLs were positively stained with the anti-FasL antibody, and the positive staining was completely abolished when the anti-FasL antibody $\mathrm{H} 707$ was replaced with antibody that had been pre-absorbed with the FasL peptide against which H707 had been generated (Fig. 1A, B). Stimulated Jurkat cells that have been shown to express FasL, were positively stained with the anti-FasL antibody (Fig. 1C, D). FasL positive cells (green) were seen in and around the islet (Fig.1E). This positive staining was completely absorbed using H707 pre-absorbed with FasL peptide (Fig. 2). This absorption experiment in immunostaining further confirmed the feasibility of our anti-FasL antibody, H707.

Monoclonal mouse anti-human CD3 (T3-4B5), CD8 (DK25), CD56 (T199) and CD68 (EBM11) were purchased from Dako-Japan. Anti-CD4 (NU-TH/I) was from Nichirei and guinea pig anti-insulin from Dako-Japan. Rabbit anti-glucagon was kindly provided by Dr. S. Iwasa (Takeda Chemical, Osaka, Japan). Secondary antibodies were biotinylated horse anti-mouse immunoglobulins (Igs), biotinylated goat anti-rabbit Igs (both fromVector Laboratories), rhodamine-conjugated goat anti-guinea pig Igs (Chemicon International), Texas red-conjugated donkey anti-rabbit Igs (Amersham International, Amersham, UK) and Texas red-conjugated sheep antimouse Igs (Amersham International).

Immunohistochemistry. An indirect immunofluorescence method was used to detect the expression of Fas and FasL. After air-drying for $30 \mathrm{~min}$, the sections were prefixed in cold acetone for $10 \mathrm{~min}$. Endogenous biotin was blocked using a biotin blocking system (Dako-Japan). The first incubation was conducted with anti-Fas or anti-FasL overnight at $4{ }^{\circ} \mathrm{C}$. After washing in PBS, the sections were incubated at room temperature for 60 min with biotinylated secondary antibodies and for an additional 30-min with FITC-avidin D (Vector Laboratories). Each section was washed in PBS, mounted with PermaFluor (Shandon/Lipshaw) and observed using a fluorescence microscope (AX-80 T and AX80TR). A double immunofluorescence method was used to determine which cells expressed Fas and FasL in and around the islet.

The above-mentioned procedure was followed by two consecutive incubations with the following antibodies: one of anti-insulin, anti-glucagon, anti-CD3, anti-CD4, anti-CD8, anti-CD56 and anti-CD68 combined with the corresponding secondary antibody. In the use of anti-CD68, Fc-receptors on macrophages were blocked with human $\gamma$-globulin (Teijin, Osaka, Japan) to exclude non-specific binding of the antibody. As a routine examination, sections were also stained with antibodies against mononuclear cells to detect insulitis, as described previously [9].

In situ TUNEL method (apoptosis detection studies). Apoptotic cells were examined by terminal dideoxynucleotidetransferase (TdT)-mediated X-dUTP nick end labelling (TUNEL) method using an in situ apoptosis detection kit (Takara Shuzo, Otsu, Japan) according to the manufacturer's instructions. Sections were air-dried for $30 \mathrm{~min}$, prefixed in $4 \%$ paraformaldehyde and made permeable with a supplied buffer. We tailed 3 '-OH fragmented DNA ends with fluorescein-labelled dUTP and detected them with horseradish peroxidase-conjugated antifluorescein antibody. Liquid DAB (3,3,-diaminobenzidine tetrahydrochloride substrate kit, Zymed Laboratories) was used as substrate. To identify the islet area, double staining with anti-insulin antibody was done.

\section{Results}

Pathological changes of the islet. Pancreatic islets were identified but showed pronounced reduction in beta cell volume in all patients which is compatible with the diagnosis of Type I diabetes. In contrast, glucagon-positive cells were not significantly reduced in the patients ( $p=0.66$ data not shown). Infiltration of lymphocytes to the islet, namely insulitis, was detected in 6 out of 13 patients, but in none of the control subjects.

Expression of Fas in the pancreas. Fas was not immunohistochemically detected in the pancreas of four control subjects (Fig. 2A). In contrast, immunoreactivity of Fas was identified in the pancreas of six patients and the Fas-positive cells were localized exclusively in the islet area (Fig. 2C, E). These 6 patients with Fas expression corresponded completely to the 6 patients with insulitis in a total of 13 patients examined (Table I). There were seven other patients without insulitis who were all negative for Fas staining in the islet. Staining of consecutive sections with antiFas and anti-mononuclear cell antibodies revealed that all the islets with the mononuclear cell infiltrate were Fas-positive.

Phenotypic analysis of Fas-positive cells. Double immunostaining for Fas and pancreatic hormones showed that islet endocrine cells were included among the Fas-positive cells. Fas-immunoreactive cells were mostly insulin-positive cells (Fig. 2C, D) and partly glucagon-positive cells (Fig. 2E, F). The prevalence of Fas expression in insulin-positive and glucagon-positive cells was analysed in five out of six Fas-positive patients. Immunoreactivity of Fas was seen in 92.2 to $97.7 \%$ (average $94.5 \%$ ) of insulin-pos- 
Table 1. Immunohistochemical findings of the pancreas biopsy specimens

\begin{tabular}{|c|c|c|c|c|c|c|c|}
\hline Case & Insulitis & $\begin{array}{l}\text { Remaining } \\
\text { beta cells }\end{array}$ & $\begin{array}{l}\text { Hyperexpression } \\
\text { of MHC class I } \\
\text { in islets }\end{array}$ & $\begin{array}{l}\text { Fas expression } \\
\text { in islets }\end{array}$ & $\begin{array}{l}\text { Number of islets with } \\
\text { Fas expression/total } \\
\text { number of islets } \\
\text { examined }\end{array}$ & $\begin{array}{l}\text { FasL expression } \\
\text { in islets }\end{array}$ & $\begin{array}{l}\text { Number of islets } \\
\text { with FasL expres- } \\
\text { sion/total number } \\
\text { of islets examined }\end{array}$ \\
\hline 2 & - & + & - & - & $0 / 6$ & - & $0 / 10$ \\
\hline 3 & - & - & - & - & $0 / 12$ & - & $0 / 15$ \\
\hline 4 & - & + & - & - & $0 / 9$ & - & $0 / 10$ \\
\hline 7 & + & + & + & + & $3 / 5$ & + & $1 / 1$ \\
\hline 8 & + & + & + & + & $12 / 12$ & ND & ND \\
\hline 9 & + & + & - & + & $13 / 16$ & + & $19 / 33$ \\
\hline 10 & - & + & - & - & $0 / 13$ & - & $0 / 4$ \\
\hline 11 & + & + & + & + & $44 / 50$ & + & $39 / 43$ \\
\hline 12 & - & + & - & - & $0 / 12$ & - & $0 / 20$ \\
\hline
\end{tabular}

ND, not determined

Table 2. Prevalence of Fas-positive cells in insulin-positive and glucagon-positive cells

\begin{tabular}{ccclc}
\hline Case & $\begin{array}{l}\text { Number of Fas- } \\
\text { positive cells/total } \\
\text { number of insulin- } \\
\text { positive cells }\end{array}$ & $\%$ & $\begin{array}{l}\text { Number of Fas- } \\
\text { positive cells/total } \\
\text { number of glucagon- } \\
\text { positive cells }\end{array}$ & $\%$ \\
\hline 5 & $83 / 90$ & 92.2 & $9 / 51$ & 17.6 \\
7 & $0 / 2$ & 0 & $4 / 38$ & 10.5 \\
8 & $109 / 114$ & 95.6 & $7 / 15$ & 46.7 \\
11 & $104 / 110$ & 94.5 & $15 / 112$ & 22.3 \\
13 & $84 / 86$ & 97.7 & $25 / 58$ & 43.1 \\
Total & $380 / 402$ & 94.5 & $60 / 274$ & 21.9 \\
\hline
\end{tabular}

itive cells (Table 2). Patient 7 was not included for the calculation of average because of the extremely small number of insulin-positive cells. Fas was detected in 10.5 to $46.7 \%$ of the glucagon-positive cells (average $21.9 \%$ ) (Table 2).

Expression of FasL in the pancreas. FasL was detected in the islet area in 5 of 12 patients examined. The islets of all these five patients showed both insulitis and Fas expression. One patient with such phenomena who was included initially in the present study (case 8) could not be analysed for FasL because of the shortage of his pancreas sections. FasL-positive cells were not detected in the pancreas of seven other patients without insulitis and four control subjects.

Phenotypic analysis of FasL-positive cells and TUNEL analysis. The phenotype of FasL-positive cells was determined in four of the five patients. In double immunostaining, FasL-positive cells were $\mathrm{CD} 4^{+} \mathrm{T}$ or $\mathrm{CD}^{+} \mathrm{T}$-cells or $\mathrm{CD} 68^{+}$macrophages (Fig. 3). A few $\mathrm{CD} 6^{+}$natural killer cells were identified in the insulitis lesion, but were FasL-negative. The prevalence of FasL expression in $\mathrm{CD} 4^{+} \mathrm{T}, \mathrm{CD} 8^{+} \mathrm{T}$ and macrophages was 37.5 to $43.5 \%, 52.4$ to $62.5 \%$ and 63.6 to
$100 \%$, respectively (Table 3 ). The percentages of $\mathrm{CD}^{+} \mathrm{T}, \mathrm{CD}^{+} \mathrm{T}$ and macrophages among FasL-positive cells were 18, 49 and $33 \%$, respectively (Table 3 ). This indicates that the most prevalent phenotype was CD8, followed by macrophages and CD4. In any case, FasL expression was not observed in islet endocrine cells. DNA strand break was not detected in the pancreas of any examined subject when assessed by the TUNEL method.

Fas and FasL expression and clinical characteristics. Fas and FasL expression were observed only in the islets of the patients with insulitis and neither Fas nor FasL was detectable in insulitis-negative patients without exception. Clinical characteristics such as patient age, sex, disease duration, urinary $\mathrm{C}$ peptide excretion, islet cell antibody status, GAD Ab status and HLA phenotype did not correlate significantly with Fas and FasL expression at the time of the disease onset (vs islet cell antibody, $p=0.79$; vs GAD ab, $p=0.73$; vs HLA-DR4, $p=0.88$; vs HLA-DR9, $p=0.88)$.

\section{Discussion}

Fas is immunohistochemically detected in many organs including the liver, kidney, intestine, lung and ovary but not in the pancreatic islet [32]. We have shown that Fas is expressed in the pancreatic islet in patients with recent-onset Type I diabetes but not in normal subjects. A clear correlation between Fas-expression and insulitis indicates that inflammatory cytokines secreted by islet-infiltrating mononuclear cells are possible inducers of the Fas expression in endocrine cells. T-cells and macrophages are the major subpopulations of the infiltrate and it is widely accepted that these cells produce various cytokines. The transcripts of interferon (IFN)- $\alpha$, IFN- $\gamma$, TNF- 

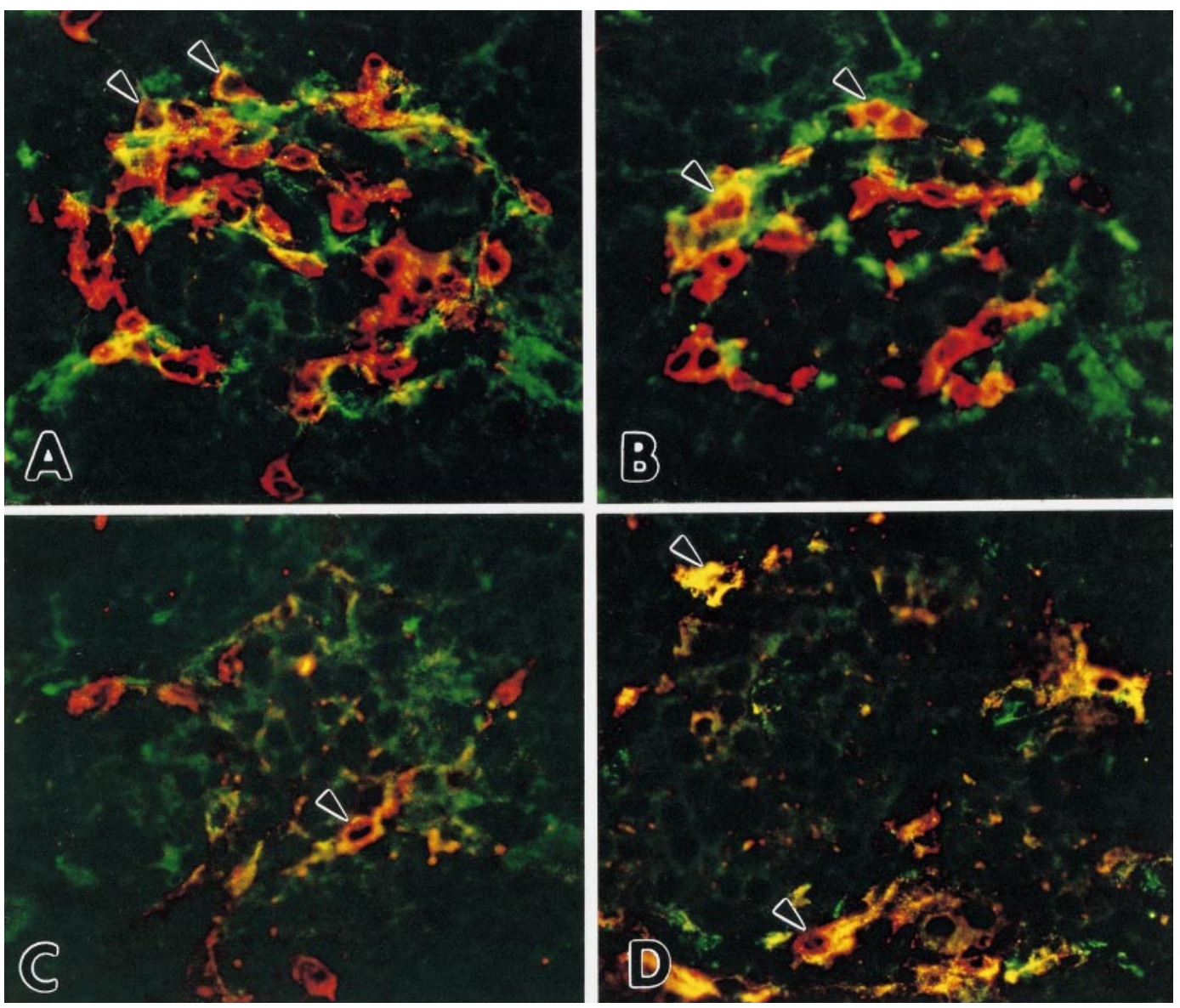

Fig.3 A-D. Consecutive pancreas sections from a recent-onset Type I diabetic patient stained with a combination of anti-FasL antibody (green) and one of anti-mononuclear cell antibodies (red; A, CD3; B, CD8; C, CD4; D, CD68) ( × 400). Representative double positive cells (yellow-orange) are indicated by arrowheads. These photographs indicate that FasL-positive cells are a fraction of $\mathrm{CD} 4^{+} \mathrm{T}$ or $\mathrm{CD} 8^{+} \mathrm{T}$-cells or $\mathrm{CD} 68^{+}$macrophages

$\alpha$, IL-1, IL-4, and IL-6 have been identified in the pancreas of Type I diabetic patients so far [10, 33, 34]. Among these, IFN- $\gamma$, TNF- $\alpha$ or the combination of the two cytokines induces Fas mRNA and antigen expression in tumour cell lines [32, 35], whereas IL-1, IFN- $\gamma$ and TNF- $\alpha$ induces Fas expression in isolated islet and beta cells $[36,37,38]$. It is, therefore, postulated that infiltrating mononuclear cells secrete cytokines leading to Fas expression on islet cells at the insulitis lesion.

Double immunostaining surprisingly showed a discrepancy in Fas expression between islet cells. Most insulin-positive beta cells expressed Fas but only some glucagon-positive alpha cells showed Fas immunoreactivity. This could be due to the different reactivity between alpha and beta cells in response to the same cytokine signals. Although the reason is not clear, such a possibility has been raised by the results of several experiments. The beta cells produced inducible nitric oxide synthase or TNF- $\alpha$ or both more efficiently than alpha cells by the stimulation of cytokines [39, 40]. Mouse insulinoma-derived cell line, $\beta \mathrm{TC} 1$, was more susceptible to cytokine-induced apoptosis than glucagonoma-derived cell line, $\alpha \mathrm{TC1}$,

Table 3. Prevalence of FasL-positive cells in islets-infiltrating mononuclar cells

\begin{tabular}{clllllll}
\hline Case & $\begin{array}{l}\mathrm{FasL}^{+} \mathrm{CD}^{+} / \\
\mathrm{CD} 4\end{array}$ & $\%$ & $\begin{array}{l}\mathrm{FasL}^{+} \mathrm{CD}^{+} / \\
\mathrm{CD}^{+} \text {cells }\end{array}$ & $\%$ & $\begin{array}{l}\text { FasL } \\
\text { M } \varnothing \text { cells }\end{array}$ & $\%$ & $\begin{array}{l}\mathrm{CD} 4: \mathrm{CD} 8: \mathrm{M} \phi(\%) \text { among } \\
\text { FasL-positive cells }\end{array}$ \\
\hline 5 & $3 / 8$ & 37.5 & $5 / 8$ & 62.5 & $7 / 11$ & 63.6 & $20: 33: 47$ \\
8 & $5 / 12$ & 41.7 & $11 / 21$ & 52.4 & $5 / 5$ & 100 & $24: 52: 24$ \\
11 & $\mathrm{ND}$ & $\mathrm{ND}$ & $34 / 57$ & 59.6 & $10 / 12$ & 83.3 & $\mathrm{ND}$ \\
13 & $10 / 23$ & 43.5 & $32 / 58$ & 55.2 & $21 / 22$ & 95.5 & $16: 51: 33$ \\
Total $^{\mathrm{a}}$ & $18 / 43$ & 41.8 & $48 / 87$ & 55.2 & $33 / 38$ & 86.8 & $18: 49: 33$ \\
\hline
\end{tabular}

Mø, Macrophages; ND, not determined; ${ }^{\text {a }}$ Case 16 is not included in the Total due to the lack of CD4 data 
probably because of lower endogenous Bcl-2 expression in $\beta \mathrm{TC} 1$ [41]. These facts indicate that the same inflammatory environment might elicit a more cytotoxic effect on beta cells than on alpha cells.

The results on expression of FasL in the infiltrating cells in our study were in good accordance with our recent finding that FasL is expressed on infiltrating cells in inflammatory lesions of ulcerative colitis, another cell-mediated autoimmune disease [42]. Another notable finding in our study was that FasL expression was observed on $\mathrm{CD}^{+}{ }^{+} \mathrm{T}$-cells and macrophages, as well as on $\mathrm{CD}^{+} \mathrm{T}$-cells, which is the most prevalent phenotype among the FasL-positive infiltrating cells. The Fas-FasL system works not only in the pathway of CTL-mediated cytotoxicity but also in a variety of regulatory mechanisms. For example, $\mathrm{CD}^{+} \mathrm{T}$-cells regulate immune systems by presenting FasL and leading Fas-bearing activated T-cells into activation-induced cell death [21]. It was also shown that macrophages could offer FasL and participate in lymphocyte depletion in human immunodeficiency virus-infected subjects [43]. As these $\mathrm{CD}^{+} \mathrm{T}$-cells and macrophages did not act in an antigen-specific or MHC class I-restricted manner, a simple interaction with Fas-bearing cells might induce a bystander killing. Although $\mathrm{CD}^{+}$T-cell-predominant infiltration in the human and mouse islets suggest that CTL-mediated beta-cell destruction is important for the development of Type I diabetes [8-10,44], the roles of $\mathrm{CD}^{+}$T-cells and macrophages have also been illustrated [45, 46]. If beta cells are prone to express Fas by cytokine stimulation, it is conceivable that Fas-FasL interaction occurs by chance between beta cells and islet-infiltrating cells, resulting in Fasmediated apoptotic death of beta cells. Of note, a recent report on two Type I diabetic patients showing the Fas expression in beta cells and FasL expression in infiltrating cells [47] is in accordance with our results. On the other hand, we did not see any FasL expression in islet endocrine cells including beta cells, although human islet cells were reported to express FasL in response to interleukin- $1 \beta$ using anti-FasL antibody from Transduction Laboratories [48].

A certain polyclonal rabbit anti-FasL Ab (C-20, Santa Cruz Biotechnology) has been reported to produce false positive reaction in flow-cytometry [49]. We had tested several anti-FasL antibodies for immunohistochemistry and flow-cytometry before starting our study. The feasibility of the anti-FasL antibody was investigated by an absorption test. In our hands, some of the commercially available antibodies showed false positive staining in the exocrine pancreas tissue. After several attempts, we decided to use H707 (Nichirei) in this study because it did not elicit false positive staining in our immunohistochemical procedure. In addition, the positive FasL staining by H707 antibody was shown to be abolished by the pre-absorption of $\mathrm{H} 707$ antibody with the FasL pep- tide, confirming the specificity of $\mathrm{H} 707$ antibody. The result of the absorption study of other anti-FasL antibodies (C-20, or anti-FasL from Transduction Laboratories) have, however, not been reported. Thus, the discrepancy of FasL staining between studies was probably due to the anti-FasL antibody used.

Apoptosis is a form of cell death induced by FasFasL interaction. It can be recognized as DNA strand breaks and the TUNEL method is commonly used for its detection in situ. Based on the finding of FasFasL expression in the Type I diabetic pancreas, we expected and looked for in situ DNA strand breaks in the insulitis lesion. The TUNEL method did not, however, show obvious apoptotic signals in any pancreas sections. This could be explained by the very short term of completion of apoptosis [50] and the considerably reduced volume of the remaining target beta cells [9]. Using NOD.scid mice that had islet cell antigen-specific T-cell receptor transgene and an accelerated course of insulitis and diabetes, it has been calculated that the average apoptotic beta cell was cleared in only $1.7 \mathrm{~min}$ [50]. If this rate was applied to wild-type NOD, fewer than four apoptotic beta cells in the whole pancreas of one mouse were expected at any one time. Because it can be assumed that the time course of human Type I diabetes is slower than that of the NOD mouse, the difficulty in detecting in situ DNA fragmentation of beta cells is not surprising in a small piece of human biopsy specimen from a pancreas.

In conclusion, our study showed that beta cells expressed Fas, and islet-infiltrating mononuclear cells expressed FasL in inflamed islets of patients with recent-onset Type I diabetes. Among FasL-positive cells, the most prevalent phenotype was CD8, followed by macrophages and CD4. These results suggest that Fas-positive beta cells could be destroyed by an interaction with FasL-positive infiltrating cells in the inflamed islets, hence Fas-FasL-mediated apoptosis might play an important part in the destruction of pancreatic beta cells in insulitis-positive, immune-mediated Type I diabetes.

Acknowledgements. We are indebted Drs. S. Tamura and S. Kawata for carrying out pancreas biopsies. We thank Dr. M. Kuwajima for being responsible for enrolment of patients, collection of clinical measurements and analysis of the data. We would like to thank Ms. K. Yamamori for excellent technical assistance.

This work was supported in part by Grants-in-aid by the Ministry of Education, Culture and Sciences in Japan, the Ministry of Health and Welfare in Japan, and the Japan Medical Association. 


\section{References}

1. Eisenbarth GS (1986) Type I diabetes mellitus. A chronic autoimmune disease. N Engl J Med 314: 1360-1368

2. Bach JF (1994) Insulin-dependent diabetes mellitus as an autoimmune disease. Endocr Rev 15: 516-542

3. Roep BO, Kallan AA, Hazenbos WLW et al. (1991) T-cell reactivity to a $38 \mathrm{kD}$ insulin-secretory-granule protein in patients with recent-onset type I diabetes. Lancet 337: 1439-1441

4. Honeyman MC, Craun DS, Harrison LC (1992) Glutamic acid decarboxylase 67-reactive T cells: a marker of insulindependent diabetes. J Exp Med 177: 535-540

5. Atkinson MA, Kaufman DL, Campbell L et al. (1992) Response of peripheral-blood mononuclear cells to glutamate decarboxylase in insulin-dependent diabetes. Lancet 339: 458-459

6. Lampeter EF, Homberg M, Quabeck K et al. (1993) Transfer of insulin-dependent diabetes between HLA-identical siblings by bone marrow transplantation. Lancet 341: 1243-1244

7. Foulis AK, Liddle CN, Farquharson MA, Richmond JA, Weir RS (1986) The histopathology of the pancreas in Type I (insulin-dependent) diabetes mellitus: a 25-yr review of deaths in patients under 20 years of age in the United Kingdom. Diabetologia 29: 267-274

8. Bottazzo GF, Dean BM, McNally JM, MacKay EH, Swift PGF, Gamble DR (1985) In situ characterization of autoimmune phenomena and expression of HLA molecules in the pancreas in diabetic insulitis. N Engl J Med 313: 353-360

9. Itoh N, Hanafusa T, Miyazaki A et al. (1993) Mononuclear cell infiltration and its relation to the expression of major histocompatibility complex antigens and adhesion molecules in pancreas biopsy specimens from newly diagnosed insulin-dependent diabetes mellitus patients. J Clin Invest 92: 2313-2322

10. Somoza N, Vargas F, Roura-Mir C et al. (1994) Pancreas in recent onset insulin-dependent diabetes mellitus. Changes in HLA, adhesion molecules and autoantigens, restricted $\mathrm{T}$ cell receptor $\mathrm{V} \beta$ usage, and cytokine profile. $\mathrm{J}$ Immunol 153: 1360-1377

11. Foulis AK, Farquharson MA, Hardman R (1987) Aberrant expression of class II major histocompatibility complex molecules by B cells and hyperexpression of class I major histocompatibility complex molecules by insulin containing islets in Type I (insulin-dependent) diabetes mellitus. Diabetologia 30: $333-343$

12. Townsend A, Bodmer H (1989) Antigen recognition by class I-restricted T lymphocytes. Annu Rev Immunol 7: 601-624

13. Kagi D, Vignax F, Ledermann B et al. (1994) Fas and perforin pathways as major mechanisms of T cell-mediated cytotoxicity. Science 265: 528-530

14. Lowin B, Hahne M, Mattmann C, Tschopp J (1994) Cytolytic T-cell cytotoxicity is mediated through perforin and Fas lytic pathways. Nature 370: 650-652

15. Kojima H, Shinohara N, Hanaoka S et al. (1994) Two distinct pathways of specific killing revealed by perforin mutant cytotoxic T lymphocytes. Immunity 1: 357-364

16. Nagata S (1997) Apoptosis by death factor. Cell 88: 355-365

17. Watanabe-Fukunaga R, Brannan CI, Itoh N (1992) The cDNA structure, expression, and chromosomal assignment of the mouse Fas antigen. J Immunol 148: 1274-1279

18. Suda T, Takahashi T, Golstein P, Nagata S (1993) Molecular cloning and expression of the Fas ligand, a novel member of the tumor necrosis factor family. Cell 75: 1169-1178
19. Hanabuchi S, Koyanagi M, Kawasaki A et al. (1994) Fas and its ligand in a general mechanism of T-cell-mediated cytotoxicity. Proc Natl Acad Sci USA 91: 4930-4934

20. Suda T, Okazaki T, Naito Y et al. (1995) Expression of the Fas ligand in cells of $\mathrm{T}$ cell lineage. $\mathrm{J}$ Immunol 154: 3806-3813

21. Dhein J, Walczak H, Baumler C, Debatin K-M, Krammer PH (1995) Autocrine T-cell suicide mediated by APO-1/ (Fas/CD95). Nature 373: 438-441

22. Chervonsky AV, Young Y, Wong FS et al. (1997) The role of Fas in autoimmune diabetes. Cell 89: 17-24

23. Itoh N, Imagawa A, Hanafusa T et al. (1997) Requirement of Fas for the development of autoimmune diabetes in non-obese diabetic mice. J Exp Med 186: 613-618

24. Allison J, Strasser A (1998) Mechanisms of $\beta$-cell death in diabetes: A minor role for CD95. Proc Natl Acad Sci 95: 13818-13822

25. Kim Y, Kim S, Kim K et al. (1999) Apoptosis of pancreatic $\beta$-cells detected in accelerated diabetes of NOD mice: no role of Fas-Fas ligand interaction in autoimmune diabetes. Eur J Immunol 29: 455-465

26. National Diabetes Data Group (1979) Classification and diagnosis of diabetes mellitus and other categories of glucose intolerance. Diabetes 28: 1039-1057

27. The expert committee on the diagnosis and classification of diabetes mellitus (1997) Report of the expert committee on the diagnosis and classification of diabetes mellitus. Diabetes Care 20: 1183-1197

28. Hanafusa T, Miyazaki A, Miyagawa J et al. (1990) Examination of islets in the pancreas biopsy specimens from newly diagnosed Type I (insulin-dependent) diabetic patients. Diabetologia 33: 105-111

29. Hakuno N, Koji T, Yano T et al. (1996) Fas/Apo-1/CD95 system as a mediator of granulosa cell apoptosis in ovarian follicle arts. Endocrinology 137: 1938-1948

30. Tanaka M, Suda T, Haze Tet al. (1996) Fas ligand in human serum. Nat Med 3: 317-322

31. Mary F, Niels K, Kevin L et al. (1998) The c-Jun N-terminal kinase cascade plays a role in stress-induced apoptosis in Jurkat cells by up-regulating Fas ligand expression. J Immunol 160: 134-144

32. Leithauser F, Dhein J, Mechtersheimer G et al. (1993) Constitutive and induced expression of APO-1, a new member of the nerve growth factor/tumour necrosis factor receptor superfamily, in normal and neoplastic cells. Lab Invest 69: 415-429

33. Yamagata K, Nakajima H, Tomita K et al. (1996) Dominant TCR $\alpha$-chain clonotypes and interferon- $\gamma$ are expressed in the pancreas of patients with recent-onset insulin-dependent diabetes mellitus. Diabetes Res Clin Pract 34: $37-46$

34. Huang X, Yuan J, Goddard A et al. (1995) Interferon expression in the pancreases of patients with type I diabetes. Diabetes 44: 658-664

35. Itoh N, Yonehara S, Yonehara M et al. (1991) The polypeptide encoded by the cDNA for human cell surface antigen Fas can mediate apoptosis. Cell 66: 233-243

36. Stassi G, Todaro M, Richiusa P et al. (1995) Expression of apoptosis-inducing CD95 (Fas/Apo-1) on human $\beta$-cells sorted by flow-cytometry and cultured in vitro. Transplant Proc 27: 3271-3275

37. Yamada K, Takane-Gyotoku N, Yuan X, Ichikawa F, Inada C, Nonaka K (1996) Mouse islet cell lysis mediated by interleukin-1-induced Fas. Diabetologia 39: 1306-1312

38. Suarez-Pinzon W, Sorensen O, Chris Bleackley R, Elliott JF, Rajotte RV, Rabinovitch A (1999) $\beta$-cell destruction in NOD mice correlates with Fas(CD95) expression on $\beta$ - 
cells and proinflammatory cytokine expression in islets. Diabetes 48: $21-28$

39. Corbett JA, Wang JL, Sweetland MA, Lancaster MA Jr, McDaniel ML (1992) Interleukin $1 \beta$ induces the formation of nitric oxide by $\beta$-cells purified from rodent islets of Langerhans. Evidence of the $\beta$-cell as a source and site of action of nitric oxide. J Clin Invest 90: 2384-2391

40. Yamada K, Takane N, Otabe S, Inada N, Inoue M, Nonaka K (1993) Pancreatic $\beta$-cell-selective production of tumor necrosis factor- $\alpha$ induced by interleukin-1. Diabetes 42 : 1026-1031

41. Iwahashi H, Hanafusa T, Eguchi Y et al. (1996) Cytokineinduced apoptotic cell death in a mouse pancreatic betacell line: inhibition by Bcl-2. Diabetologia 39: 530-536

42. Ueyama H, Kiyohara T, Sawada N et al. (1998) High Fas ligand expression on lymphocytes in lesions of ulcerative colitis. Gut 43: 48-55

43. Badley AD, McElhinny JA, Leibson PJ, Lynch DH, Alderson MR, Paya CV (1996) Upregulation of Fas ligand expression by human immunodeficiency virus in human macrophages mediates apoptosis of uninfected $\mathrm{T}$ lymphocytes. J Virol 70: 199-206

44. Wong FS, Visintin I, Wen L, Flavell RA, Janeway CA Jr (1996) CD8 T cell clones from young nonobese diabetic
(NOD) islets can transfer rapid onset of diabetes in NOD mice in the absence of CD4 cells. J Exp Med 183: 67-76

45. Haskins K, McDuffie M (1990) Acceleration of diabetes in young NOD mice with a $\mathrm{CD}^{+}$islet-specific $\mathrm{T}$ cell clone. Science 249: 1433-1436

46. Hutchings P, Rosen H, O'Reilly L, Simpson E, Gordon S, Cooke A (1990) Transfer of diabetes in mice prevented by blockade of adhesion-promoting receptor on macrophages. Nature 348: 639-642

47. Stassi G, De Maria R, Trucco G et al. (1997) Nitric oxide primes pancreatic $\beta$ cells for Fas-mediated destruction in insulin-dependent diabetes mellitus. J Exp Med 186: 1193-1200

48. Loweth AC, Williams GT, James RFL, Scarpello JHB, Morgan NG (1998) Human islets of Langerhans express Fas ligand and undergo apoptosis in response to interleukin- $1 \beta$ and Fas ligation. Diabetes 47: 727-732

49. Smith D, Sieg S, Kaplan D (1998) Technical note:Aberrant detection of cell surface Fas ligand with anti-peptide antibodies. J Immunol 160: 4159-4160

50. Kurrer MO, Pakala SV, Hanson HL, Katz JD (1997) $\beta$ cell apoptosis in T cell-mediated autoimmune diabetes. Proc Natl Acad Sci USA 94: 213-218 